\title{
地震の確率予報
}

\author{
東京大学地震研究所* 佃 為 成 \\ Earthquake Forecast based on Probability
}

\author{
Tameshige TsukUDA \\ Earthquake Research Institute, The University of Tokyo, Yayoi1-1-1, Bunkyo-ku, \\ Tokyo 113-0032, Japan
}

(Received April 9, 2002; Accepted February 12, 2003)

\begin{abstract}
A new probability process model for earthquake forecast is presented based on Bayesian treatment. The prior probability at the beginning of this process is estimated from long-term data from earthquake history and active fault activities in a target area. The posterior probability is deduced from Bayes' theorem in terms of the prior probability and two conditional probabilities: "alarm rate" and "null alarm rate". The former is defined to be the probability that a precursory anomaly is detected on condition that an earthquake is accompanied, and the latter to be that on condition that no earthquake is accompanied. These probabilities are estimated mainly by statistical tests of previously accumulated observation data. The test consists of trials of detecting anomaly during each assigned detecting period and of registering earthquake events during the corresponding hypothetical forecasting period. Regarding the estimated posterior probability as the prior probability for the next step of the Bayesian process, we will obtain a new posterior probability when data from another anomaly event is input into the process. Successive application of this procedure continues to renew the posterior probability until a dicision is made to issue an earthquake warning. The final posterior probability $p_{N}$ for $N$ independent anomaly observations with alarm rate $q_{i}$ and null alarm rate $s_{i}$ for $i$ $=1,2, \cdots N$ is given by

$$
p_{\mathrm{N}}=\frac{x_{1} x_{2} \cdots x_{\mathrm{N}}}{x_{1} x_{2} \cdots x_{\mathrm{N}}+a_{1}} \sim p_{0} x_{1} x_{2} \cdots x_{N}
$$

where $p_{0}$ is the first prior probability, $a_{1}=\left(1-p_{0}\right) / p_{0}, x_{i}=q_{i} / s_{i}$ and the approximation $(\sim)$ is valid if $p_{N}$ $\ll<$. The well known terms, "secular probability" and "success rate" are interpreted in the above framework to be a prior probability and the induced posterior probability, respectively. The ratio of alarm rate to null alarm rate, i.e., $x_{i}$ in the above formula, for each precursory anomaly observation is a key factor for reliability on earthquake prediction. The probability gain, i.e., the ratio of the posterior probability to the prior probability, is approximated to be the product of the above ratios.
\end{abstract}

Key words: earthquake prediction, earthquake forecast, probability, alarm rate, null alarm rate.

\section{\&1. 序論}

地震予知とは地震の場所, 大きさ, 発生時刻を予め知 るという意味であり, 地震の発生をある条件のもとで予 測することと言い換えてもよい. 予測には確率を用い る. そのわけは，第一に地震現象そのあのが不確定な要 素に支配されているからであり，第二にわれわれのあつ 予知観測情報にも不確定さがあるからである。したがっ て, 予知を行う実際のプロセスとしては, ある条件のあ

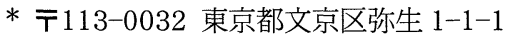

とでの確率予測に帰する．地震予知は社会的な背景をも つので, 予測結果は予報として発表されることを念頭に おかねばならない，その意味で，確率予測をここでは確 率予報と呼ぶ.

わが国では，地震の “永年的発生率” [宇津 (1999)］と 予知の “適中率” [宇津 (1977), 宇津 (1982)］という概念 が定着しており，予知の確率を論ずる場合によく活用さ れている. 適中率とは予知の試みをした場合の地震発生 予測が適中する確率のことである，また，予知すべき地 震の数のうち前兆現象が伴った数の割合を示す “予知 
率” [宇津 (1977)］という確率もよく使われている. 日 常, この予知率を地震発生の確率 (適中率) と勘違いし たり，不完全なデー夕から形式上の “適中率”を求め, 真の “適中率” と考えてしまった議論もしばしば行われ ている [\&3. 参照]. その原因の一つとして, 確率の種類 がいろいろあり，それらの意味がどのように異なるのか がわかりにくいせいああると思われる.さらに, 多項目 観測の予知への効果を見積もる確率的手法がこれまで明 解に示されていなかったため, 極めて小さい“永年的発 生率”から実用的なレベルの “適中率”をどのようにし て得るのか, つまり永年発生率に対する適中率の比（確 率利得) [Aki (1981)］を如何に著しく増大させるかにつ いてはっきりした見通しが得られず, 地震予知の向上に 悲観的な見方をする向きむあった.

以上のようなこれまでの概念だけに立脚していたので は確率の体系の理解が困難であり, 誤解を招きやすい. ところが, 確率の考え方をべイズの定理に基づく事前確 率や事後確率の枠組みに当てはめてみたところ, 比較的 簡単な表現による体系に収まることがわかった。“永年 発生率” は事前確率, “適中率” は事後確率に他ならない ことが示される.そして, 新たな観測情報の入手に伴い, 事後確率を次のステップの事前確率とし, 新たな事後確 率を生み出していくことによって “確率” が時間の進行 ととあに変化していくことを簡単に示すことができる. 観測情報による “予知率” は, 一つの条件付き確率とな るが， あう一つの条件付き確率として “空報率”［例え ば，陸 (1985)] が浮かび上がってくる．これは今まであ まり注目されていなかった概念である。ささらに予知率と 空報率の比が予知の信頼性に深く関わっていることが明 らかになる.この小論の目的は, このように重要な事柄 を容易に導きだすことができるべイズ流の地震予報確率 推定の原理的手法を示すことである．その応用について は別の機会に述べることにする.

\section{§ 2. 確率予報の方法}

\section{1 大前提}

地震予報を行う対象や手続きについて，一定のモデル やルールを設ける. まず, 予報の対象となる地震や地域 について以下のような前提ないし仮定を設ける.

P1) 対象とする地震は或る一定の規模以上とする (主に被害を及ぼす大地震)。これはP2)の対象地域の広 さなどにあ依存する.

P2）対象地域を予め設定しておく，予報で発表され る地震発生予想地域つまり，地震発生を監視する地域 と，観測のための異常現象監視地域は必ずしも同一の広 がりをもつものではない，後者は，観測項目によっても
異なる。

つぎに，予報の内容や時間関係について定める.

P3）予報を発表スタイルにすると，「どの地域におい て，今からどれくらいの期間によ゙れくらいの大きさの地 震が発生する確率がどれくらいです」のような表現とな る.

P4）予報は任意の時間に行うことができる．実際の 場合は, いずれかの観測項目に異常現象が認められた場 合に試みることになるであろう。予報の試みを行う時刻 とその結果を発表する時刻の間には, 実際は, ずれを生 じるが，ここでは簡単のため，そのずれを無視して同時 刻とみなし，それを予報時刻と呼ぶ。予報を試みたもの の, 確率が一定の基準に達しない場合には発表を行わな いこともある. 予報時刻を遡った一定の期間について, 異常現象検出を試み, この時刻より未来の一定の期間を 対象に予報を行う. 時間関係の詳細はつぎの 2.2 に述べ る.

最後に, 観測する現象についての前提条件を掲げる.

P5) 注目する現象やその異常の判定については, そ の特徴などについて予め定義をしておく．場合により定 義の内容は, つぎの仮定 P6) や P7) にも関係してくる.

P6) 各観測項目のデータは統計的に独立であるとす る. それぞれの観測項目の異常信号は, 地震との統計的 因果関係はあるが，互いには統計的因果的な関係がない とする. ある地震発生に従属する各信号は, いずれす互 いに相関があるのではないかという疑問が湧く．そのよ うな場合もあるであろうが, 統計的に独立な信号群も存 在し得る.よく吟味した上で, 信号間に従属関係がない 項目を選ぶ. はっきりしない場合は独立と仮定せざるを 得ない. 従属関係の例として, ある地点における地壳変 動の 2 方向の各傾斜成分を取り上げる，どちらかに異常 が出現すれば，他方にも現れる可能性が高い。この 2 成 分データは，必ずしも常に従属関係にあるとは断定でき ないが，独立と考えることは差し控えるのが順当であろ う。このように互いに従属する観測項目があれば,一纏 めにしてしまう。補足であるが，従属性をあつ観測デー 夕も重要である，これは情報として圥長になるが，観測 精度や確度を向上させる利点がある.

P7) 同じ種類の観測データでも, その時定数が大き い現象と小さい現象がある. そのような場合は, 時定数 による区別を行い，別々の独立した観測項目として取り 扱う。

\section{2 検知対象期間と予報対象期間}

観測デー夕の異常の検出には, 観測している現象に固 有な時間経過を必要とする，予報時刻から遡ったある一 定の観測期間（検知対象期間と呼ぶことにする）に異常 
が検出されたとき, 予報時刻の直後から一定期間内（予 報対象期間と呼ぶことにする）に地震が発生するか，し ないか, この 2 つの事象の生起確率を求める. Fig. 1 に, 予報時刻, 検知対象期間, 予報対象期間の関係を示した. 一つの観測項目については, 検知対象期間, 予報対象 期間の長さはそれぞれ一定とする，予報時刻は刻々，一 定の間隔でずらす。その際, その予報時刻に対する検知 対象期間, 予報対象期間も移動する. 通常, 検知対象期 間に異常データが確認された場合に予報を試みる.

Fig. 2 に，その様子を描いた.

今，検知対象期間や予報対象期間の長さの順番に観測 項目を考え番号を付ける. 観測項目 $i$ についての検知対 象期間と予報対象期間は，例えばそれぞれ $T_{d, i}, T_{f, i}$ $\left(T_{d, i}>T_{d, i+1}, T_{f, i}>T_{f, i+1}\right)$ とする. 実用的には, この階 層は, 例えば, 10 年, 5 年, 1 年, 半年, 3 力月, 1 力月, 2 週間, 1 週間, 3 日, 1 日のように区切るのが分かりや すい. それぞれの期間に当てはまる現象が存在し, 長期 から短期に亘って次々に異常が検出されるならば, 予報 の精度や確度は向上する.

ここに設定した時間の枠組みは，実際の予報の実行を 想定しているが，つぎの 2.3 で述べる異常現象の観測と その先行現象としての評価を行うための観測時間の枠組 みをあ提供する。

\section{3 試行実験}

予報確率を求めるには, 異常現象と地震発生を結ぶ データが必要である。それぞれ一定の長さをむつ検知対 象期間と予報対象期間を，過去の仮想的な予報時刻に対 して設定する. 長期観測の中で， Fig. 1 のような期間を ランダムに多数抜き出し，それぞれの検知対象期間にお いて異常のあるなしに関わらず，対応する予報対象期間 に地震が発生したかどうかを記録する。これを試行実験 と呼ぼう。これを繰り返し, 試行実験の最終的な集計結
果は, Table 1 のようにまとめることができる. このよ うな表は統計学では二值事象の四分割表 $(2 \times 2$ 分割表 $)$ として知られており, 地震予知情報の整理にも用いられ る [例えば, 菊池 (1999)].

この表の作り方はこうである. 1 回の試行に対して, 検知対象期間において異常が検出されたかされなかった か，予報対象期間において地震が発生したかしなかった か, それぞれ 2 つの場合の計 4 つの場合に対応する箱の どれかに 1 を加算する.この 4 種類のうちの 1 種類の結 果をあたらす試行について, 各種類の回数が箱に記録さ れていくことになる. その回数をデータとして, 地震が 発生した場合に先行異常を検出した確率（地震を記録し た試行の回数のうち, 先行異常を検出した回数の割合, あるいは全地震回数に対する先行異常を伴った地震回数

予報時刻 forecasting time

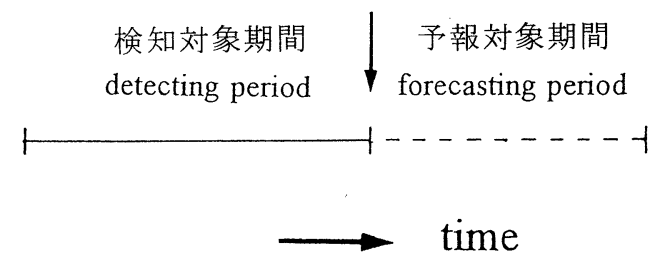

Fig. 1. Forecasting time $\left(t_{f}\right)$, anomaly detecting period $\left(T_{d}\right)$ and forecasting period $\left(T_{f}\right)$. When an earthquake forecast is assesed, we check whether any anomaly would be detected in observation data during the assigned anomaly detecting period prior to the forecasting time, and issue an alarm to the public if the probability that an earthquake will occur during the assigned forecasting period is estimated to be higher than an assigned threshhold.

\section{予報時刻 \\ forecasting time}

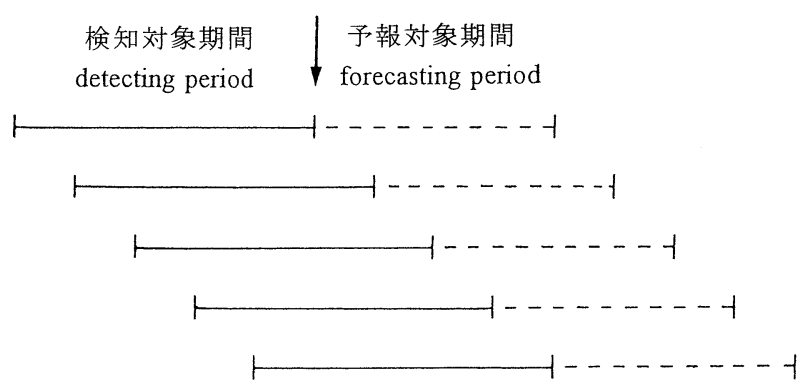

Fig. 2. Shift of the forecasting time due to the passage of time. The detecting period and forecasting period are correspondingly shifted. 
Table 1. $2 \times 2$ contingency table for earthquake events and precursory signal events. Statistical experiment is performed by testing data of earthquake events and precursory anomalies of a specific kind. The anomalies and earthquake events are detected in the same time framework shown in Fig. 1. For each statistical trial, we count up either of the numbers $m, n, \mu, \nu$ registered in four boxes.

\begin{tabular}{lcccc}
\hline & \multicolumn{4}{c}{ 検知対象期間の前兆的信号 (Precursor) } \\
\cline { 2 - 5 } & あり (Yes) & あり (Yes) & なし (No) & 合計 (Total) \\
\hline \multirow{2}{*}{$\begin{array}{l}\text { 予報対象期間の地震 } \\
\text { (Earthquake) }\end{array}$} & なし (No) & $n$ & $\mu$ & $M$ \\
& 合計 (Total) & $F$ & $\nu$ & $N$ \\
\end{tabular}

$M=m+\mu, N=n+\nu, F=m+n, G=\mu+\nu, T=M+N=F+G$

予知率 (alarm rate): $q=m / M$

空報率 (null alarm rate): $s=n / N$

の割合）や，地震が発生しなかったにあかかわらず異常 を検出した確率（地震を記録しなかった試行の回数のう ち異常を検出した回数の割合）を算出する. 前者は, わ が国では “予知率” (alarm rate) [宇津 (1977)], 後者は, 中国に打いて “空報率” [例えば，陸 (1985)］と呼ばれて いる. 本論文では, 後者の英語表記を null alarm rate と する. 予知率 $q$, 空報率 $s$ は Table 1 の表記を用いると それぞれ, $q=m / M, s=n / N$ となる. 大地震を対象にし

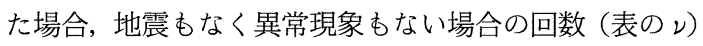
が他の場合に比べ抜きんでて多いということを念頭にお かねばならない。

データ収集のための試行実験において, 予知率や空報 率を推定するため, 個別の地震によらない一般的な異常 現象の特性に注目するのであれば， ある地域の地震発生 予測に対して，他の地域において得たデー夕をあ用いる ことができる， $2 \times 2$ 分割表を作成するとき，P2) あるい は場合によってはP1) の前提をはずし, 同じような状況 の他の地域の現象についてもデー夕を取り込むのであ る.

\section{4 先行異常現象（前兆現象）と条件付き確率}

前兆現象は, 必ずしも地震を起こす原因となる現象 (前駆現象) ばかりではない. 地震の発生準備過程におい て, 2 次的に派生する現象も前兆現象としての資格があ る. また, 現象を発現させる環境が整っていない場合に は, 先行異常現象として検知できない. 地殻変動のよう な前駆現象と考えられる現象でも, 観測機器の設置環境 に支配され, 異常を検出できるかどうかは, 前駆現象に しろ, 派生現象にしろ, 一定の条件下の確率現象と考え られる. 充分多くの試行実験に基づけば， 2.3 で得られ た“予知率”之“空報率” は, それぞれ, 地震が発生し たという条件のとき先行異常を検知する確率, および, 地震が発生しなかったという条件のとき先行異常と見な
してしまう確率と考えることができる.これらは一般 に，条件付き確率と呼ばれる.

\section{5 事前確率と事後確率}

プレート運動によってもたらされる地殻の変形や応力 場の変動を主な原因として, 地域毎に固有の地震活動度 をあつ.その過程やメカニズムがいかに複雑であって あ, 長年の地震発生履歴デー夕に最適な統計モデルを当 てはめることにより，地震発生確率を推定できる．この 確率を用いて地震発生を予測することができる，長期予 知の手法である. 今, 次の仮定を置く.

P8) 対象とされる地震の発生については, 予報を行 う以前に，すでにある確率が与えられているとする（一 般的に事前確率と呼ぶ). この確率は, 過去の大地震の歴 史デー夕に基づく. 活断層の調査から推定されることも ある.

ただしこの場合，その確率の值は一般的に非常に小さ い. そこで, 実用的な予知を行うため先行異常現象の デー夕を活用しよう。地震が発生するか，しないかの 2 つの場合についての条件付き確率（予知率および空報 率）が得られているわけであるから, 先の長期予知によ る確率を事前確率として採用すれば, 前兆現象に付随し た条件付き確率を用いて事後確率を求める定理（Bayes の定理）により，検知対象期間において異常を検出した 場合に予報対象期間における地震発生の確率（事後確 率）を算出できる.

\section{6 定 式 化}

予報対象期間内に地震が発生する事前確率 $p_{0}$ が与え られているとする. 観測項目 $i$ に対する予知率を $q_{i}$, 空 報率を $s_{i}$ とする. 観測項目 1 についてのみ情報を得てい るとき, 予報対象期間に地震が発生する確率 $p_{1}$ は, Bayes の定理より， 
$p_{1}=\frac{p_{0} q_{1}}{p_{0} q_{1}+\left(1-p_{0}\right) s_{1}}=\frac{x_{1}}{x_{1}+a_{1}}$,

ここで,

$$
x_{1}=\frac{q_{1}}{s_{1}}, \quad a_{1}=\frac{1-p_{0}}{p_{0}} .
$$

式 (1) を可視化したものが Fig. 3 のリング状のグラフで ある。

集合論の記号を用いるならば, $p_{0}=P(E), 1-p_{0}=P\left(E^{c}\right)$, $p_{0} q_{1}=P(1 \mid E),\left(1-p_{0}\right) s_{1}=P\left(1 \mid E^{c}\right)$ と書ける. ここで, $E$ は地震が発生する事象を表し， $E^{c}$ はその背反事象，すな わち地震が発生しない事象を表す。また, $P(E)$ は事前の 地震発生確率, $P(1 \mid E)$ は地震が発生したとき前兆 1 が 発生する確率, $P\left(1 \mid E^{c}\right)$ はその地震が発生しなかったと きにその前兆が発生する確率である。これらの確率の領 域が図のリングに表示されている。事後確率 $P(E \mid 1)$ は 図にも説明があるように式 (1) となる.

つぎに $N$ 個の観測項目に対して異常が検出されたと きの地震発生確率を求めてみよう. 異常現象の独立性に 関する前提条件 P6) (2.1) に加えて, 以下の仮定を設け る.

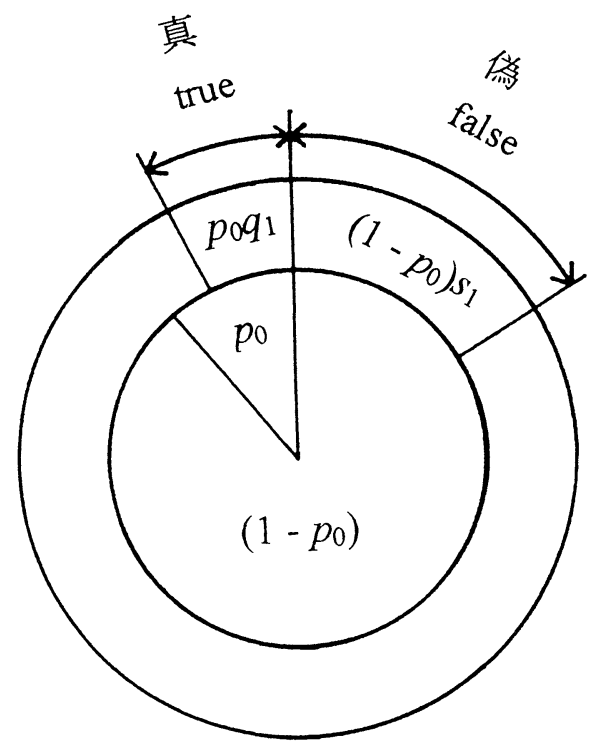

probability $=$ true $/($ true + false $)$

$$
p_{1}=\frac{p_{0} q_{1}}{p_{0} q_{1}+\left(1-p_{0}\right) s_{1}}
$$

Fig. 3. Probability ring. It is very easy to derive Eq.(1) through inspection of this figure.
P9）予報対象期間の長さは，すべての観測項目にお いて同じとする.

まず，第 2 番目の観測項目について，その予知率，空 報率を用い, $p_{1}$ を今度は $p_{0}$ の代わりに事前確率と考え ると，式 (1) にならい，観測項目が 2 つあるときの事後 確率として,

$$
p_{2}=\frac{p_{1} q_{2}}{p_{1} q_{2}+\left(1-p_{1}\right) s_{2}}
$$

を得る.ところで, 式 (1)より,

$$
\frac{1-p_{1}}{p_{1}}=\frac{a_{1}}{x_{1}}
$$

であるから, 式 (3) は,

$$
p_{2}=\frac{x_{2}}{x_{2}+a_{2}},
$$

と書き換えられる。ただし，

$$
x_{2}=\frac{q_{2}}{s_{2}}, \quad a_{2}=\frac{a_{1}}{x_{1}} .
$$

数学的帰納法により, $i$ 番目の観測項目のデータが得ら れた場合には，そのときの事後確率 $p_{i}$ は,

$$
p_{i}=\frac{x_{i}}{x_{i}+a_{i}}
$$

ただし，

$$
x_{i}=\frac{q_{i}}{s_{i}}, \quad a_{i}=\frac{a_{i-1}}{x_{\mathrm{i}-1}} .
$$

したがって，式 (7) を用いて事前確率を次々に繰り込ん でいけば， $N$ 個の観測項目があるときは,

$$
\begin{aligned}
p_{N} & =\frac{p_{0} q_{1} q_{2} \cdots q_{N}}{p_{0} q_{1} q_{2} \cdots q_{N}+\left(1-p_{0}\right) s_{1} s_{2} \cdots s_{N}} \\
& =\frac{x_{1} x_{2} \cdots x_{N}}{x_{1} x_{2} \cdots x_{N}+a_{1}}
\end{aligned}
$$

が得られる. 式 (9) は，Fig. 4 を視察することにより直 接導くこともできる.ここで， $s_{i}>0$, すなわちゼロには ならないと仮定した．純粋理論的にはゼロああり得るの であるが，そのときは或る $i$ に対し， $s_{i}=0$ となるので, 結局 $p_{N}=1$ である. 以上の多項目観測の式においては, それぞれの観測項目に対して予報対象期間の長さと予報 時刻は一致していなければならないが，検知対象期間の 長さは異なってもよい.

仮定 P9) によって予報対象期間を一定としたが，過去 の観測データの整理の仕方によってこの期間の長さが異 なってくる場合も多いと思われる. また, 短期予知や直 前予知の段階に入ると, 予報対象期間を短くしていく必 要がでてくる，その場合には，漸化式を用いる段階で, 事前確率として採用した確率を次の観測項目に対する予 報対象期間に適合するように修正する。まず，式 (2), (4), (8) 加ら導汃れる漸化式 


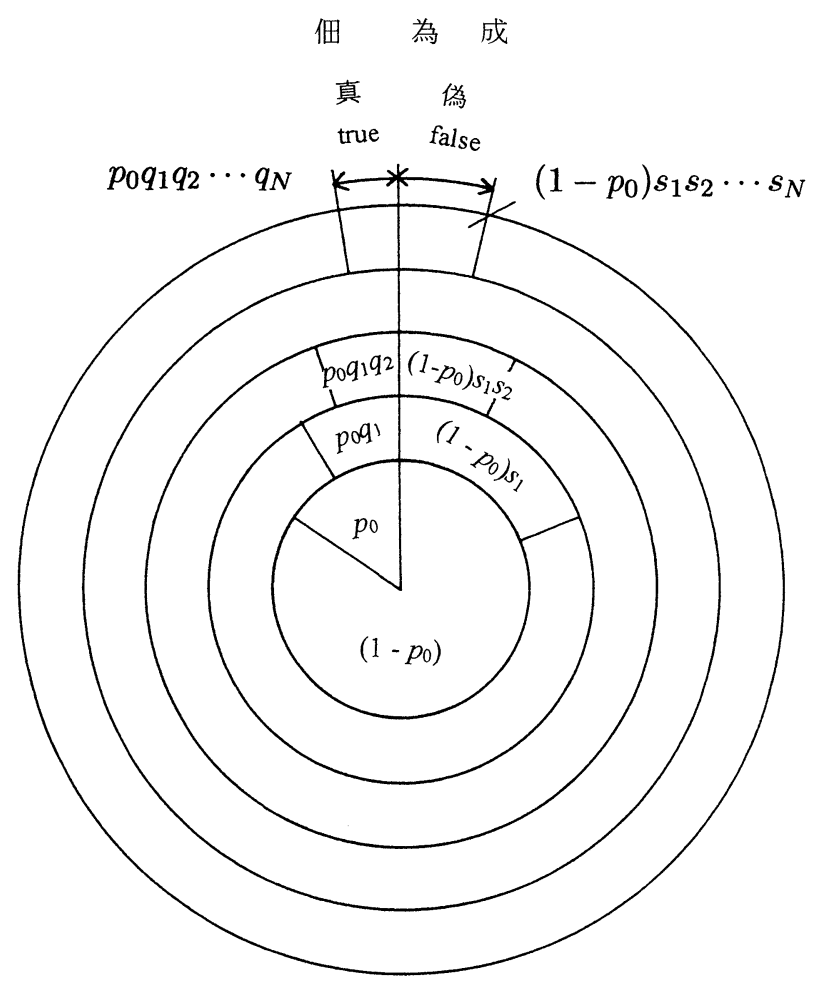

Fig. 4. Probability ring for many observation items. It is very easy to derive Eq. (9) through inspection of this figure.

$$
a_{i}=\left(1-p_{i-1}\right) / p_{i-1}
$$

を用意する．この式は，一つ前の事後確率のみからパラ メー夕 $a_{i}$ を決定できることを意味している.これを利用 すれば, 観測項目 $i-1$ に対して $p_{i-1}$ が与えられたとき, 次の観測項目 $i$ の予報対象期間に適合するように $p_{i-1}$ を修正して $p^{*}{ }_{i-1}$ と記せば, 式 (11) および (7) の代わり に次のような漸化式を用いればよいことがわかる.

$$
a_{i}=\left(1-p^{*}{ }_{i-1}\right) / p^{*}{ }_{i-1}, \quad p_{i}=x_{i} /\left(x_{i}+a_{i}\right)
$$

最初の事前確率についても, 予報対象期間の長さに応じ て修正する。

実用上は, 各観測項目のうち, 設定されている予報対 象期間が最も短いものに適合するよう適宜修正してお く. 修正方法については, 予報対象期間の長さに比例さ せることがまず考えられる，統計モデルを考案してもよ い.それぞれの観測項目によって修正方法が異なっても よい，地震がランダムに発生し, Poisson 過程が適用さ れる場合の地震発生確率についての予報対象期間の修正 公式はUtsu (1983)に与えられている.

\section{7 予知率/空報率}

式(10)において, $a_{1}$ は式 (2) から $p_{0}$ のみの関数で, その他の項は $x_{i}$ (予知率/空報率) の積から成り立ってい るので, 予報確率に対する観測デー夕の効果は各観測項
目の予知率/空報率の積で決まると云える. 一般的に $p_{0}$ は非常に小さいので, 式 (2) より, $a_{1} \sim 1 / p_{0}$ である. し たがって, 式(10)は，ほぼ

$$
p_{N} \sim \frac{p_{0} x_{1} x_{2} \cdots x_{N}}{p_{0} x_{1} x_{2} \cdots x_{N}+1}
$$

のように近似できる.さらに, 観測項目 $i$ の (予知率/空 報率） $x_{i}$ のそれぞれが大きな值をとらず， $p_{0} x_{1} x_{2} \cdots x_{N}$ む 1 に比べ格段に小さいならば, 式 (13) は,

$$
p_{N} / p_{0} \sim x_{1} x_{2} \cdots x_{N}
$$

となる. 式 (14) の左辺は事後確率/事前確率（特に最初 の事前確率) を表し, 条件付き確率がどれだけ貢献した かを確率の倍率で示している. 事後確率が小さい值であ る間は, この倍率は各観測項目の予知率/空報率の積で 表現される. 事後確率はすなわち地震発生確率である. 我々は各観測項目の予知率/空報率を予め知っておい て, 前兆を検出したときに, 地震発生確率がまだ非常に 小さいうちは式(14), それが数 10\%のように 1 に近い 值になってきたら厳密な式 (10) から地震発生の確率を 推定すればよい，もともとの事前確率が小さな值（例え ば 10-4)でむ, 多くの独立な観測項目のデー夕に異常が 検出されれば, 事後確率すなわち地震予報確率 (地震発 生確率）を実用的なレベル（数 10\%）まで高めることが 可能となる. 


\section{$\S 3$. 議論}

2.6 の結果を従来の方法で導き出すにはどうすればい いか, これを検討しておくのも地震予知の確率の理解を 深めるためには大いに意義がある．地震予報の確率とし ては, “適中率” [宇津 (1977), 宇津 (1982)] という概念 がある。また “永年的発生率” [宇津 (1999)] という用語 あある. Table 1 の表記法を用いるならば, 地震の永年 的発生率は $p_{0}=M / T$, 適中率は $p=m / F$ である. ただ し，このときの試行実験は，永年（文字通りの）の観測 に基づくことが条件である. 一方, 予知率は $q=m / M$, 空報率は $s=n / N$ である. $p, p_{0}, q, s$ を Table 1 の量, $m$, $n, \mu, \nu$ を用いて表現すれば,

$$
p=\frac{p_{0} q}{p_{0} q+\left(1-p_{0}\right) s}
$$

の関係が得られる。これは，式(1)に対応するものであ るが，㛜密には，同一ではない，式(1)において， $p_{0}$ は永 年的発生率だけではなく，もっと広い意味の事前確率を 表している. 予知率と空報率は, $2 \times 2$ 分割表に基づく点 では，同一と見なしてよい．著者は現在，具体的なアイ デアをもち合わせていないが，この表に基づかない予知 率や空報率の推定法むあり得る。また，観測項目によっ ては，地域についての前提条件 P2) の制限を越えて，広 い地域からデー夕を取る場合もあるであろう。予報の出 発点となる $p_{0}$ の推定と，予知率抢よび空報率の推定に は，別々のデー夕を用いることが可能なのである．前者 の推定には注目する地域の長期的なデータが不可欠であ るが，後の二つは， $2 \times 2$ 分割表作成の説明 $(\$ 2,2.3)$ の 最後に付記したように, 事例を広く世界中に求めれば, 比較的短期の観測によっても推定することができる。 そ の場合の分割表は，いろいろな地域の地震のデー夕が混 在しているので, その表から求める $p$ や $p_{0}$ は, 注目して いる地域の地震の適中率や永年的発生率を表していない ことになる。

本論文で提示した方法は，ある時点で事後確率であっ た確率が今度は事前確率に “役割交代 “するので， $p_{0} や$ $p_{i}$ は固定した名称（永年発生率のような）をむたない上 いう点でも考え方が異なる.

結局，特定地域に対する永年観測に基づく, $2 \times 2$ 分割 表のパラメータ $p$ や $p_{0}$ を用いた従来の式 (15) は, 本論 文の式 (1)に括いて, 事前確率として地震の永年的発生 率を採用した場合の応用の例にすぎない. 式(15) から式 (1) が導き出されるわけではけっしてない. \$2.に拈いて 見てきたように，長期予知デー夕に基づく永年的発生率 だけではなく，2×2 分割表から求めた地震発生率は統 計的に有意ではない場合でも，いろいろな情報から得ら れた中期予知的，あるいは短期予知的な地震発生確率も
事前確率として利用できる. 式 (1) は広い適用範囲をむ つのである.ところで, 徒来の考え方に基づく Utsu (1983) の式 (23)，(32) は表現スタイルは異なるが，それ ぞれ式 (1)，(9) に対応する.

ここで, 補足的に $2 \times 2$ 分割表の利用についての注意 点を述べる．注目する地域について永年の観測に基づく データであれば，求められる適中率や永年的発生率は正 しい. しかし，大きな地震の場合，地震発生の頻度は非 常に低いのであるから，永年の観測デー夕を得ることは ほとんど不可能だと考えてよい. 永年観測の表は机上の 理論（思考実験）のためと言っても言い過ぎではない， 実際的な分割表は，ある異常現象が前兆現象としてどの くらい予知に利用できるかを調べる目的で, 各地のデー 夕を集計してこしらえるものである $(\S 2,2.3)$. この際重 要な点は，この表による適中率や永年的発生率は形式的 なあのだということである．特定の地域の地震発生につ いては何も云えない. 実際, 永年的発生率 $p_{0}$ は単独の地 域のデータによるものに比べ，值は大きくなっている． なぜならば，多くの地域の地震回数が加算されているか らである.したがって, 式 (15) より, 適中率として計算 される值 $p$ 屯本来の值よりは大きな值をもつ.

形式的な思考の結末の例を挙げよう。異常現象が発現 した場合だけのデータ, すなわち, Table 1 において, $m$ と $n$ だけを記録し，異常が検出された回数のうち，実際 に地震が発生したのは何回あったかという確率（適中 率) を $p=m /(m+n)$ と求める. そして，「観測に異常が 見つかった中で, 地震が発生したのが $m$ 回あり, 発生し なかったのが $n$ 回あった. 今, その異常が見つかったの で, $m /(m+n)$ の確率で地震が発生する」と言う.一見よ さそうに思われる. \$2. に述べた理論によると，異常現 象の評価のためには, 予知率/空報率の情報が必須であ

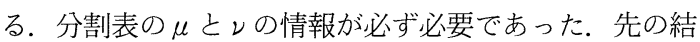
果には合点がいかない. どうしてこのような䛊りが生ず るかというと, デー夕取得の前提条件を忘れているため である。このようなことを言うためには, 注目する地域 における永年の観測による膨大な試行回数（とくにレが 多い）のデータが必要である，実際の場合，とくに大地 震が対象の場合, 実際の観測デー夕から予報のための地 震発生確率 (適中率) を直接求めることはほぼ不可能と 考えなくてはならない.

“適中率”についてさらに補足しておきたい。この言葉 の意味は,「地震発生を予測したとき適中する確率」であ る. $2 \times 2$ 分割表に基づくならば，適中率とは，「異常現 象が検出された場合に地震が発生する確率」である。条 件付き確率の表現である，予知率のような条件付き確率 と同じ様な確率に思えて, 多少混乱が生ずる。適中とい 
う言葉を挿入すると,「異常現象が検出された場合に地 震発生を予測したとき適中する確率」であるといった具 合に表現が長くなり，多くの人が滅入ってしまう。条件 付き確率の様を呈するのは, まさに異常現象が発生する 確率を問題にする場合の条件付き確率の一つだからであ る.一方，本論文で採用した表現に徹すれば，考え方が すっきりする. 事後確率については, 何かの条件が加 わったとき，もとは事前確率だったものが “整形”に よって “変身”するから事後の確率だと考える. 事前確 率については, 基本的には過去の経過やそのとき課され た条件を問わない. だから，事前確率のことを先験的 (アプリオリの）確率と呼ぶことむある，第 $n$ 番目まで の観測項目から得られた事後確率 $p_{n}$ を次の事前確率に 用いて，それに対する事後確率 $p_{n+1}$ を得る手続きの根 拠の一つは, 各観測項目が独立であるという仮定に由来 する. その前の条件によらず, 独立に地震発生確率（事 後確率) を更新できるわけである.この小論では適中率 という言葉を用いず, 地震発生確率が事前確率, 事後確 率の連鎖を通して変化していくと捉えるのである.

Aki (1981) によって提唱された確率利得, すなわち, 適中率/永年的発生率は, 本論文の体系では事後確率/事 前確率 (特に最初の事前確率) となる. 式 (14) の左辺の 量 $p_{N} / p_{0}$ を確率利得とみなすことができる. 確率利得を 増加させるには, 各観測項目に対する予知率/空報率の 積を増加させればよい. 地震予知観測研究の中で, 地震 が伴った異常現象の記述はされるが, 地震を伴わなかっ た異常現象の記載が少ない. 後者む重要な情報であっ て, その研究が異常現象の理解に繫がり, 予報確率の精 度を向上させる. 大地震は希な現象であるから, 地震が ないときの研究は忍耐力を要するが, 後者の情報ととも に, ノイズの研究にとっても, 欠かすことが出来ない. このような研究の重要性を認識すべきである. また, 一 つの観測項目によってもたらされる予知効果はそれほど 大きくない場合が多いので, 多種項目の観測が必要であ る.このことを認識していない予知研究者屯多い. 確率 の值を実用レベルまで上げるには, 多くの独立な異常現 象検出が必要である.

地震予知に関係ある “確率” はこれまでに述べたもの 以外にも存在する. 特定地域の永年の観測に基づく $2 \times$ 2 分割表を分析すれば，いろいろな確率を考案すること ができる. 分割表の 4 変数 $m, n, \mu, \nu$ は独立変数である. それらを用いて, 確率 $f$ は一般に次のように表すことが できる.

$$
f=\frac{a_{1} m+a_{2} n+a_{3} \mu+a_{4} \nu}{b_{1} m+b_{2} n+b_{3} \mu+b_{4} \nu} .
$$

ここで, $a_{i}, b_{i}$ は 1 または 0 の值をもつ. また, $f \leq 1$ を満
足するようにそれらの定数を選ぶ. 地震予知に関して意 味のあるあのは, 分母が 2 項で分子が 1 項の場合に 4 種 類, 分母が 4 項で分子が 2 項の場合に 2 種類の合計 6 種類である.ただし, $f$ と $1-f$ の対は 1 種類とした. 確 率 $f$ の中で, 3 個の独立なあのを選ぶことができる. 1 組の例は, $p=m /(m+n), q=m /(m+\mu), s=n /(n+\nu)$ で ある. その他の確率は, すべて, これら $p, q, s$ の関数と して表すことができる.これをまず示そう。 $n$ は $m$ の関数, $q$ の式から $\mu$ を $m$ の関数, $s$ の式から $\nu$ を $m$ の関数として表す.これを式 (16) へ代入すると, $m$ が約分されて, $f$ は $p, q, s$ だけの関数となるので, 証明 が終わる. 独立な確率として $p_{0}, q, s$ としてもよい. $p$ と $p_{0}$ は式 (15) で関係づけられている. 本論文で示したべ イズの方法に拈いても独立な確率として, 事前確率 $p_{0}$, 予知率 $q$, 空報率 $s$ を考えればよかった。 事後確率 $p$ は ベイズの定理から導かれる，予報確率評価のためには, 上の 4 種類の確率の概念が必要にして十分なものであ る. 分割表による方法の方が確率の種類が多いが, それ は, 異常現象の発生の確率を問題する場合を含んでいる からである. その問題に対しては, ベイズの方法では別 のシステム（地震デー夕に基づく異常現象予報）を組む ことになるのである. そのことを含めると, ベイズの方 法はこの分割表に現れるすべての基本的（予測に必要 な）な確率を取り扱うことができる.

地震予報に関する 4 種類の確率は 2 種類に分類でき る. 一つが地震発生確率 (事前確率と事後確率) であり, あう一つが条件付き確率（予知率と空報率）である. 別 の言い方をすれば，前者は地震予報確率として活用でき る確率であり, 後者はそれを生み出すための “装置”の “部品”のような役割をする確率である. その装置は, 多 段 “増幅器”を内蔵している. それぞれの利得は, 予知 率/空報率で与えられる. 地震予知研究の仕事は, 畢竟, これらの増幅器を開発することであると言える.

地震予報の確率は, 地震が発生するか, しないかの 2 つの事象についてどちらがどのくらい確かなのかを問題 にするあので, 確率論の最む初歩的なあのである. にも かかわらず, 予知研究においても, 予知の実践に関する 論議においても充分活用されているとは云えない，確率 予報の考え方を普及させるには, 本論文に示したベイズ の方法がわかりやすい. そして, 集合論の記号の代わり にグラフを用いて表現した Fig. 3 やFig. 4 の効用は, 式 (1)，(9) をいと屯簡単に導くことができる点であった が，数式に不慣れな人でも理解が容易になる点も捨てら れない，また，地震発生確率が事前確率から事後確率へ 之変換されるときの, 条件付き確率の役割は何か, 事前 確率に対しどのように作用し, どのように条件を付ける 
のかということを図から会得できる点も教育的である. 地震予報確率は, 事前確率になったり事後確率になった りしながら変化していく．その変化を起こさせるきっか けになるのが異常現象検知であり, 変化を起こす作用を するのが条件付き確率である.

活断層の長期予報において, 例えば「今後 100 年以内

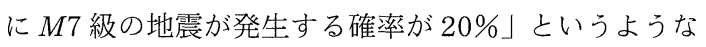
発表がなされると, 人間活動の時間スケールに対して予 測対象期間が長く, 確率の值も小さいことなどから，防 災関係者や一般住民からは，具体的によ゙うすればよいか 分からないという反応が返ってくる.このような形式の 発表には, 地震予知プロセスの中の第一段階であるこ と, そして今後, 地震予報の確率や予報対象期間は, わ れわれが自然からの情報を得ることによって時々刻々変 わっていくあのであることが説明されていない点に問題 がある．長期から短期の各段階に応じた “確率予報”之 防災対策が存在することを広く認識してもらう必要があ る.

2.6 における漸化式の流れは, 予報確率が新たな観測 情報を入手する度に変化していくことを表現している. そして, 予報確率の時間経過を定式化することができ る。地震予報確率が規定值を超え, 警報が発令されたと し，その後の異常データの状況によっては，確率值が低 くなっていくことも考えられる。そ場合は，一度発令 した警報を解除することができるようなシステムも構築 できるであろう。その具体的な議論は別の論文にゆだね ることにして，ここでは，ベイズの方法を用いることに よって，様々な面の応用についての展望が開けることを 示唆するに止める.

\section{§4. 結論}

この小論の立場は，観測デー夕（異常データ）の入手 に伴って，したがって時間経過に伴って，地震発生確率 がどのように変化していくかを見ることである. 従来, 地震予知に関係する種々の “確率” の概念がいわば並列 的に提示され，それらの関係の “構造”がわかりにく かった. 本論文の方法では, これらの確率を, “地震発生 確率” とその補助的な確率 (条件付き確率) に分類し, 確率の概念として結局 4 種類に絞ることができた．実践 的予報を前提にした異常現象の監視と地震予報のための 対象期間を念頭に置き, 条件付き確率を推定するための 統計的な試行 (実験) を設定した。 その試行の結果を 2 $\times 2$ 分割表に表現して，なぜ従来の立場では種々の混乱 が生じやすいのかを分析し，また，地震予知において重 要な“確率”の考えの普及のために本方法が果たす教育 的役割についても論じた，様々な地域の観測データから
は条件付き確率の推定は可能であるが，このデー夕から 或る地域の地震発生確率を直接求めることは事実上不可 能であることも指摘した，実際の観測デー夕から推定で きるのは, 予知率や空報率であって, 地震発生確率につ いては, その值をどのくらい高められるのかということ しかわれわれには推定できない. 本論文の主な結果をま とめると以下のようになる.

1) 地震予知の確率の枠組みをベイズの定理に基づい て構築した。予報プロセスのモデルを表現するために必 要かつ十分な確率の種類は, 地震発生の事前確率, 条件 付き確率 (予知率と空報率), それに地震発生の事後確率 である. 観測データに異常が検出されると, その観測項 目の条件付き確率を活用することになる，新たな異常観 測データの入手によって，いままでの事後確率が今度は 事前確率に置き換わり, 次の事後確率を生む. 予報を発 表しようとする時刻までに得られた最終的な事後確率が すなわち地震予報確率 (地震発生確率) である.

2) 従来の地震予報確率の概念である適中率はベイズ の方法の枠組みでは, 地震の永年的発生率を事前確率と 考えたときの事後確率に他ならない，ある地域の永年観 測による $2 \times 2$ 分割表の 4 個の变数から作り出される確 率は, いずれる基本的な 3 個の独立な確率で表現でき る. そして独立な確率として, 永年的発生率, 予知率, 空報率を選ぶことができる，適中率は，これらの関数と して求められる.これは, ベイズの定理によって, 事後 確率が事前確率, 予知率, 空報率加求められることに 対応している.

3）空報率の重要性を示した.これはベイズの定理の 枠組みの中で必要な要素であり, 予知情報としての信頼 性に深く関わっている. 予知率と空報率が，この枠組み の条件付き確率で, 前者は地震が伴うという条件で異常 が検出される確率, 後者は地震が伴わない条件で異常が 検出される確率である. 予報確率の值を向上させる因子 は，予知率/空報率である。

4) 多項目観測のデータの場合, 各観測項目の予知 率/空報率の積が近似的に予報確率の増加率を与える. それぞれの予知率/空報率の值 $(\geq 1)$ がさほど大きくな い場合であっても, 数多くの独立な観測デー夕に異常が 検出されれば，予報確率を実用のレベルまで向上させる ことができる.

\section{謝辞}

地震予知に関心を持ちの多くの方々との日頃のディ スカッションにおいて考えさせられることが多かった. また, 査読者松澤 暢氏ほかの方々には表現の不備や説 明不足の事柄について貴重なコメントをいただいた。こ 
れらの方々に深く感謝いたします.

\section{参考文献}

Aki, K., 1981, A probabilistic synthesis of precursory phenomena, in Earthquake Prediction: An International Review, edited by D. W. Simpson and P. G. Richards, A. G. U., Washington, D. C., 566-574.

菊池 聡, 1999, 宏観異常現象の報告を歪める認知的要 因，地震ジャーナル，28，35-43.

陸 遠 忠篇, 1985 , 地震予報の地震学的方法, 268 $\mathrm{pp}$, 地震出版社 (中国). 宇津徳治, 1977, 地震予知の適中率と予知率, 地震 2, 30, 179-185.

宇津徳治, 1982, 地震予知の適中率と予知率 (第 2 報), 地震研究所彙報, 57, 499-524.

Utsu, T., 1983, Probabilities associated with earthquake prediction and their relationships, Earthq. Predict. Res., 2, 105-114.

宇津徳治, 1999, 地震活動総説, 東京大学出版会, 876 pp. 